ram. The project was led by cardiac surgeon Marthanda Sankaran Valiathan, who retired last year as the institute's director. Valiathan had worked with Charles Hufnagel, at Georgetown University Medical Center in Washington, DC. Hufnagel (now deceased) is the person who in 1951 developed the first mechanical valve.

"It took us 14 years to reach the present stage," says A. V. Ramani, a key member of Valiathan's research team and now vice-president of TTK Pharma Ltd - the company that has been licensed to manufacture the valve at its factory in Bangalore. The company plans to produce 10,000 valves a year and will sell them in India for about Rs12,000 ( $\$ 400)$ each. The valve has been tested to international standards, and already an estimated 20 per cent of Indian surgeons are using it.

The chitra device is of the 'tilting' kind - one of three types of mechanical heart valve now in use. It consists of a disc that opens and closes inside a housing called the 'cage', and a 'sewing ring' made of polyester fabric that enables the surgeon to attach the device to the heart muscle. While existing valves use carbon composite for the cage, the new chitra valve is made of a chrome-cobalt (called Haynes 24) alloy. It is also the only valve that uses a disc made of ultra-high-molecularweight, high-density polyethylene - a tough biocompatible material that is already being used in orthopaedic prosthetic devices.

The polyethylene was developed at National Chemical Lab in Pune, manufacturing methods were perfected at Hindustan Aircraft Ltd and scientists at the Indian Institute of Science in Bangalore advised on the choice of materials.

Clinical trials have been carried out at six sites in addition to the Sri Chitra Tirunal Institute. Because of its commercial potential, development of the valve has been fully funded by the National Research Development Corporation, the agency responsible for marketing home-grown technologies. "We spent under US $\$ 65,000$ on its development," says the agency's managing director N. K. Sharma, "but much more on patenting it."

The intellectual property rights will be held by the development corporation, which has filed patent applications in the USA, Germany, the UK, Japan, France, Bulgaria, Romania, Belgium and Austria. Although offers to license the technology were received from some European firms, they were politely shelved in order to allow an Indian company to get a foothold in the valve market.

To be fully accepted, most heart surgeons agree that a device like a heart valve must have a stamp of approval from a regulatory agency similar to the US Food and Drug Administration. "Right now, we only have the word of its developers and the company that will sell it," says one leading cardiac surgeon. "That is not enough."

KS JAYARAMAN Freelance writer, New Delhi

\title{
DID YOU KNOW?...
}

\section{Louis Jeantet Foundation names prizewinners}

The 10th annual Louis Jeantet European prize for medicine will be awarded in April to two teams of two researchers and one individual.

This year's prizewinners are Dirk Bootsma and Jan $\mathbf{H}$. J. Hoeijmakers, professors at the Erasmus University of Rotterdam, The Netherlands, noted for their studies of the DNA repair system; Peter N. Goodfellow, professor of Genetics at Cambridge University, and Robin Lovell-Badge, head of Developmental Genetics at the Medical Research Council's National Institute for Medical Research in London, codiscoverers of the testis-determining gene sry; and Peter Gruss, director of the Department of Molecular and Cell Biology at the Max-Planck Institute of Biophysical Chemistry, Göttingen, Germany, who is perhaps best known for his studies of vertebrate embryonic development.

Gruss, and the teams of Bootsma and Hoeijmakers, and Goodfellow and LovellBadge, will each receive a cumulative research award of $\mathrm{Sf1.8}$ million (US $\$ 1.4$ million). Each will also receive a substantial personal award. The Louis
Jeantet Prize, which honours the present rather than the past, is open to researchers involved in basic or clinical medical research in one of the member countries of the Council of Europe, although prizewinners themselves do not have to be European nationals.

The award ceremony is to be held in Geneva, Switzerland.

D.G.

\section{Misconduct enters pop culture}

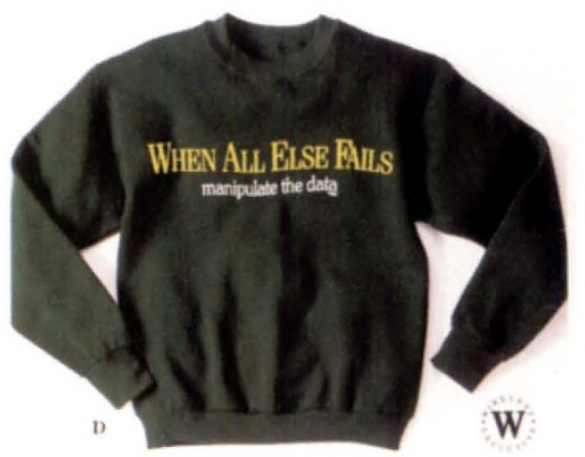

Researchers often lament the lack of public understanding of science, wishing that science and appreciation of science were part of mainstream culture. Well, now they are.

The Wireless catalogue is selling a snappy green sweatshirt $(50 / 50$ cotton blend) and a T-shirt ( $100 \%$ cotton) that adjure: "When All Else Fails manipulate the data." Text for the ad takes the case further: "hey, it works for science... why not for you?"

This may be good for business but is bad news for science.

\section{Liddy Dole at Mass General}

In health policy circles, managed care is all the rage these days. Medical insurance comes packaged to cut costs, in part, by limiting a patient's choice of doctor. After all, one physician is as good as another.

That this runs counter to what Americans, at least, really believe is evident in the case of Liddy Dole, the president of the Red Cross and wife of Senate majority leader Robert Dole. A resident of both the state of Kansas and the nation's capital, Dole went to the Massachusetts General Hospital in Boston when she needed carotid artery surgery. Neurosurgeon Robert Ojemann has a reputation for being the best there is and Dole obviously wanted the best. So much for managed care.

B.J.C. 